Vol. 6(1997): 173-182.

\title{
Feeding value of grass ensiled with absorbents assessed in growing lambs
}

\author{
Riitta Sormunen-Cristian
}

Agricultural Research Centre of Finland, Institute of Animal Production, FIN-31600 Jokioinen, Finland, e-mail: riitta.sormunen-cristian@mtt.fi

Päivi Mannerkorpi

Agricultural Research Centre of Finland, Institute of Animal Production, FIN-31600 Jokioinen, Finland, Current address: Ministry of Agriculture and Forestry, PO Box 232, FIN-00171 Helsinki, Finland

\begin{abstract}
Four absorbent materials incorporated into grass at ensiling were compared in terms of their effects on silage quality, effluent production, diet digestibility, ad libitum intake and growth of lambs. The materials used (50 $\mathrm{kg} \mathrm{t}^{-1}$ grass) to retain silage effluent flow were molassed and unmolassed sugar beet shreds (MSBS, SBS), a commercial product (CP) based on MSBS $(75 \%)$ and wheat bran $(20 \%)$, and rolled barley (RB). With the exception of MSBS and a control (C2), all silages were ensiled with formic acid solution. Unmolassed sugar beet shreds were also ensiled with a granulated formic acid product (grFA). The silages were fed to 56 Finnish Landrace lambs for 21 days.

Silage effluent retention rates were similar (1.44-1.55 $\mathrm{kg} \mathrm{kg}^{-1}$ absorbent) for the sugar beet shredbased absorbents but zero for RB. The organic matter digestibilities of the diets were not affected $(p>0.05)$ by the silage absorbent treatment. The digestibility of SBS silage was, however, improved by grFA as an additive. Silage intake was generally increased by absorbent inclusion, and was about $29 \%$ higher in lambs receiving silages treated with sugar beet shreds than in those receiving untreated silages. The daily growth rate of lambs was highest with the SBS treatment $(124 \mathrm{~g})$ followed by SBS ensiled with grFA (108 g) and MSBS (86 g); it was lowest with RB (36 g). With regard to effluent chemical oxygen demand, digestibility and silage intake, the use of SBS as an absorbent material is recommended by ensiling with either liquid or grFA.
\end{abstract}

Key words: barley, chemical oxygen demand, effluent, silage, sugar beet shreds

\section{Introduction}

Silage made from direct-cut grass containing less than $300 \mathrm{~g}$ of dry matter (DM) $\mathrm{kg}^{-1}$ produces a highly polluting effluent (Gordon 1967). One of the main strategies in seeking to reduce effluent production is to incorporate absorptive materials into the grass at ensiling. Cereal grains are generally considered less absorptive than fibrous materials (Dexter 1961), but marked absorption has been reported under both laboratory condi- 


\section{AGRICULTURAL AND FOOD SCIENCE IN FINLAND}

\section{Sormunen-Cristian, $R$. \& Mannerkorpi, P. Feeding value of grass ensiled with absorbents}

tions (Spörndly 1986) and farm conditions (Done 1988, Jones et al. 1990). An ideal absorbent is expected not only to reduce effluent flow but also to have positive effects on silage feeding value and animal performance. A previous small-scale experiment identified materials which, when ensiled with grass, may reduce effluent losses (Mannerkorpi and Toivonen 1993). The purpose of the present study was to confirm these earlier findings using an ensiling technique which more closely resembles that used on a farm. Further, a common dietary energy supplement, barley, was tested as an effluent absorbent, and silage quality was examined using molassed sugar beet shreds (MSBS) without the widely applied formic acid silage additive. The effects of various absorbent materials on silage quality, effluent production, diet digestibility and the ad libitum intake and performance of growing lambs were tested.

\section{Material and methods}

\section{Ensiling study}

Seven silages were simultaneously prepared in identical 1-tonne capacity fibreglass-walled round silos (volume $1.5 \mathrm{~m}^{3}$, diameter $1.4 \mathrm{~m}$ ) using second-growth direct-cut timothy-fescue (50\% Phleum pratense and 50\% Festuca pratensis) grass taken on 27th and 28th August 1993 by flail harvester. The silos were fitted with individual drainage systems for collecting and monitoring effluent production and composition. Samples of harvested material were collected from each load and the grass for each silo was weighed. The materials used to stem silage effluent flow were molassed and unmolassed sugar beet shreds (MSBS, SBS), a commercial product (CP) and rolled barley (RB). The CP (a special compound feed manufactured by Suomen Rehu, Finland) was based on molassed sugar beet shreds $(75 \%)$, wheat bran $(20 \%)$, malted barley $(3.4 \%)$, plant oil $(1.0 \%)$ and Na-benzoate $(0.6 \%)$.
The absorbents were sprinkled in layers at a rate of $2.5 \mathrm{~kg}$ of absorbent per $50 \mathrm{~kg}$ of grass fresh weight (50 $\mathrm{kg} \mathrm{t}^{-1}$ grass). The control silages (C1 and $\mathrm{C} 2$ ) were prepared without absorbents. With the exception of MSBS and the control (C2), all silages were ensiled using AIV2 solution ( $80 \%$ formic acid, $2 \%$ orthophosphoric acid) at a rate

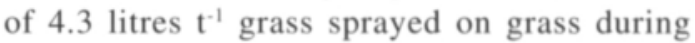
harvesting. Unmolassed sugar beet shreds were also ensiled with the same amount of formic acid in a granulated form (grFA) (Kemira Chemicals, Finland). The grFA ( $55 \%$ porous substance, i.e. damolin, $18 \%$ formic acid, $10 \%$ phosphoric acid) was added by hand in layers to the grass at ensiling $\left(22.7 \mathrm{~kg} \mathrm{t}^{-1}\right)$. Each silo was tightly sealed with plastic after filling and weighted with concrete blocks, $500 \mathrm{~kg} / \mathrm{m}^{2}$. Silage effluent production was measured and sampled $(10 \%)$ daily for the first two weeks and thereafter weekly until the silos were opened. Effluent samples were immediately frozen. The silage retention rate was calculated as follows (in $\mathrm{kg}$ ): (control silage effu- $_{\text {. }}$ ent - experimental silage ${ }_{\text {effluent }}$ /incorporated absorbent.

\section{Animal trial}

After a preservation period of 20 weeks, the silos were opened and the silages removed, mixed well, sampled and vacuum-packed in smaller portions for the feeding trial and stored about for 10 days in a sheep barn (maximum temperature $+15^{\circ} \mathrm{C}$ ) before the trial started. Fifty-six Finnish Landrace lambs with an initial weight of $38 \mathrm{~kg}$ (SD 5.1) and an initial age of 147 days (SD 5.6) were allocated by weight and sex into seven groups in a randomised block design. The lambs were housed individually in galvanised metal cages (measuring $1.2 \times 2.2 \mathrm{~m}$ ) with three feed-bins and a water nipple. In a preliminary study, daily grass silage DM consumption (mean $58 \mathrm{~g} \mathrm{~kg}^{-1}$ live weight ${ }^{0.75}$ ) was determined to establish the daily portions to be fed to the animals. Each group of eight lambs was offered its respective silage for 21 days. To balance the feed ration, the daily diet consisted of $200 \mathrm{~g}$ of soya- 


\section{AGRICULTURAL AND FOOD SCIENCE IN FINLAND}

Vol. 6 (1997): 173-182.

bean meal (crude protein $512 \mathrm{~g} \mathrm{~kg}^{-1} \mathrm{DM}$ ) and silage ad libitum to allow refusal of $10 \%$ of the silage allowance. A mineral mixture $(\mathrm{Ca} / \mathrm{P}=1.8)$ and salt $(\mathrm{NaCl})$ were added at $20 \mathrm{~g}$ and $10 \mathrm{~g} \mathrm{lamb}^{-1}$ day $^{-1}$, respectively. The amount of silage offered and refused was recorded for each animal. Silage and feed refusal samples were collected daily during the last seven study days. Faecal samples were taken from each animal twice a day during the last five study days. Silage and faecal samples were immediately frozen.

\section{Chemical analysis}

The DM content of the feeds, feed refusals and faecal samples was determined by oven drying at $105^{\circ} \mathrm{C}$ for $24 \mathrm{~h}$. The DM content of the silages was corrected as in Huida et al. (1986). The feed analyses of grass, silages, refusals and faeces were conducted according to standard procedures. In addition, the silages were analysed for total and water-soluble nitrogen by the Kjeldahl method, for ammonium nitrogen (McCullough 1967), pH and lactic acid (Barker and Summerson 1941), for volatile fatty acid by gas chromatography (Huida 1973, Huida et al. 1986) and for water-soluble carbohydrates (Somogyi 1945) and ethanol (Huida 1982). The amounts of neutral detergent fibre (NDF) and acid detergent fibre (ADF) in silages were determined according to the methods of Robertson and Van Soest (1981). The digestibility coefficients for soyabean meal were taken from the feed tables (Salo et al. 1990). The apparent digestibility of the diets was determined using acid insoluble ash as an internal marker on the last five days of the trial (Van Keulen and Young 1977). The digestibility of the silages was calculated by the difference method (the diet - soya bean meal). The metabolisable energy (ME) of the experimental feeds was calculated according to MAFF (1975). The effluent samples were analysed for DM, crude protein by the Kjeldahl method, and water-soluble carbohydrates (Somogyi 1945). The chemical oxygen demand (COD) of the effluent was colorimetrically determined by the Hach method (Hach Company, Colorado, U.S.A.).

\section{Statistical analyses}

Data on organic matter (OM) digestibility, intake of $\mathrm{OM}$, intake of digestible $\mathrm{OM}$ and the growth rate of the lambs were analysed with the GLM procedure (SAS 1992). The model was as follows:

$Y_{i j k}=m+A_{i}+B_{j(i)}+C_{k}+d_{i j k}$, where $Y_{i j k}$ is the observed response (e.g. OM digestibility), $\mathrm{m}$ is the overall effect, $A_{i}$ the effect of block $i$ $(\mathrm{i}=1 . .8), \mathrm{B}_{\mathrm{j}(\mathrm{i})}$ the effect of animal $\mathrm{j}$ within block $\mathrm{i}$ $(j=1 . .56), C_{k}$ the effect of treatment $k(k=1 . .7)$ and $d_{i j k}$ the residual error. The effect of treatments was evaluated using the following contrasts: SBS $+\mathrm{RB}+\mathrm{CP}$ vs. C1, MSBS vs. C2, SBS(FA) vs. SBS(grFA) and SBS vs. CP.

\section{Results and discussion}

The weather before ensiling was dull and showery but not rainy. The grass contained (with standard deviations) dry matter $157 \mathrm{~g} \mathrm{~kg}^{-1}(11.4)$, crude protein $143 \mathrm{~g} \mathrm{~kg}^{-1} \mathrm{DM}$ (5.6), crude fibre $282 \mathrm{~g} \mathrm{~kg}^{-1} \mathrm{DM}$ (2.4), ash $93 \mathrm{~g} \mathrm{~kg}^{-1} \mathrm{DM}$ (1.7) and water-soluble carbohydrates $102 \mathrm{~g} \mathrm{~kg}^{-1} \mathrm{DM}$ (8.5). The chemical composition of the absorbents is given in Table 1.

\section{Silage effluent and chemical oxygen demand}

The results given in Table 2 indicate that none of the absorbents could totally retain the effluent. The MSBS absorbent treatment without the use of formic acid additive was the most effective in retaining effluent $\left(1.58 \mathrm{~kg} \mathrm{~kg}^{-1}\right)$ followed by SBS, SBS ensiled with grFA and CP. The absorption ability of the sugar beet shreds was 


\section{AGRICULTURAL AND FOOD SCIENCE IN FINLAND}

Sormunen-Cristian, $R$. \& Mannerkorpi, P. Feeding value of grass ensiled with absorbents

Table 1. Chemical composition of the absorbents used in the study.

\begin{tabular}{lrrrr}
\hline & SBS & RB & CP & MSBS \\
\hline DM, g kg-1 & 897 & 881 & 891 & 883 \\
In DM, g kg-1 & & & & \\
Ash & 39 & 25 & 69 & 57 \\
Crude protein & 118 & 148 & 129 & 125 \\
Ether extract & 4 & 20 & 20 & 5 \\
Crude fibre & 186 & 46 & 163 & 154 \\
N-free extract & 653 & 761 & 619 & 659 \\
\hline
\end{tabular}

SBS = unmolassed sugar beet shreds, $\mathrm{RB}=$ rolled barley, $\mathrm{CP}=$ a commercial product based on molassed sugar beet shreds $(75 \%)$ and wheat bran $(20 \%)$, MSBS $=$ molassed sugar beet shreds, $\mathrm{DM}=$ dry matter

thus better than in the study of Kennedy and Moore (1988) (1.0 1 effluent $\mathrm{kg}^{-1}$ absorbent). Rolled barley was the most ineffective absorbent for controlling effluent loss; effluent flow from RB silage was twice as high as that from MSBS silage and even higher than that from the control silage. These findings differ from those of Done (1988) and Offer and Al-Rwidah (1989), who found a significant reduction in effluent production when $\mathrm{RB}$ was incorporated into grass at ensiling. According to Jones et al. (1990), incorporation of RB may reduce effluent flow by up to $50 \%$. Johnson (1992) found, however, that inclusion of $40 \mathrm{~kg}$ of RB had no effect on total effluent production, whereas rates of $60 \mathrm{~kg}$ and $80 \mathrm{~kg}$ showed progressively more effect on effluent flow. Here the amount of RB $\left(50 \mathrm{~kg} \mathrm{t}^{-1}\right.$ grass) used was, therefore, probably too low for efficient effluent retention. The use of formic acid in granulated form instead of liquid form did not affect the effluent retention rate.

There were clear differences in chemical composition between the effluents produced by the different silages. The mean DM of effluent produced from silages treated with sugar beet shreds was $45 \mathrm{~g} \mathrm{~kg}^{-1}$, which is in close agreement with that reported by Purves and McDonald (1963) for farm silos $\left(40 \mathrm{~g} \mathrm{l}^{-1}\right)$. With the exception of RB silage, the absorbent-treated silages showed lower DM losses than untreated silages. However, effluent from the treated silages contained more sugar and crude protein than effluent from the corresponding control because the nutrients of the absorbents were also solubilized. The use of MSBS without any acid preservative resulted in a smaller amount of sugar in effluent than did unmolassed silage treated with formic acid. This was attributed to the hydrolytic effect of formic acid (compare $\mathrm{Cl}$ with $\mathrm{C} 2$ ), which was used in combination with the SBS treatment.

The polluting strength of an effluent is described by its chemical oxygen demand (COD). The most environmentally friendly combination of absorbent and silage additive in terms of high retention rate and low COD content of effluent was SBS with grFA. The silage preserved with grFA had lower nutrient losses and COD than the silages treated with FA. Only the effluent of C1 silage had a lower COD content; this silage had, however, higher effluent production. The use of MSBS instead of SBS increased the COD of the silage effluent (MSBS 53.2 vs. SBS 43.4), which is consistent with the findings of a previous small-scale experiment (Mannerkorpi and Toivonen 1992). The COD values of 33.7-53.2 $\left(\mathrm{mg} \mathrm{l}^{-1} \times 10^{3}\right)$ are in agreement with those presented by Jones et al. (1990).

\section{Chemical composition of silages}

The chemical composition and quality of silages at silo opening are given in Table 3 . The average DM content of the control silages during the ad libitum feeding period was $209 \mathrm{~g} \mathrm{~kg}^{-1}$ but that of the silages containing absorbents $219 \mathrm{~g} \mathrm{~kg}^{-1}$ (Table 4). Incorporation of sugar beet shreds has been found to increase the silage DM content (Offer and Al-Rwidah 1989). Silages treated with sugar beet shreds had a lower crude protein content than untreated or RB treated silages owing to the dilutive effect of the absorbents with markedly lower crude protein contents than in grass. Comparison of the formic acid-treated silages showed that SBS and CP inclusion raised the sugar content but that RB silage, in which etha- 
Vol. 6 (1997): 173-182.

Table 2. Effects of absorbent inclusion and formic acid treatment on effluent quantity, composition, dry matter losses, retention rate and chemical oxygen demand.

\begin{tabular}{|c|c|c|c|c|c|c|c|}
\hline \multirow{3}{*}{$\begin{array}{l}\text { Absorbent } \\
\text { Silage additive }\end{array}$} & \multicolumn{7}{|c|}{ Silages } \\
\hline & $\mathrm{Cl}$ & SBS & SBS & RB & $\mathrm{CP}$ & $\mathrm{C} 2$ & MSBS \\
\hline & FA & FA & grFA & FA & FA & - & - \\
\hline Grass, kg & 1000 & 875 & 1000 & 900 & 1000 & 1000 & 1000 \\
\hline Absorbents, kg & - & 43.8 & 50 & 45 & 50 & - & 50 \\
\hline \multicolumn{8}{|l|}{ Effluent: } \\
\hline Amount, $\%$ of grass FM & 22.4 & 17.3 & 17.7 & 26.1 & 18.0 & 21.0 & 13.1 \\
\hline DM, $\mathrm{g} \mathrm{kg}^{-1}$ & 37 & 47 & 38 & 43 & 48 & 42 & 48 \\
\hline DM losses, \% & 5.3 & 4.0 & 3.3 & 5.6 & 4.3 & 5.6 & 3.1 \\
\hline Sugar, $\mathrm{g} \mathrm{kg}^{-1}$ & 12 & 18 & 13 & 15 & 19 & 4 & 7 \\
\hline Crude protein, $\mathrm{g} \mathrm{kg}^{-1}$ & 7 & 9 & 8 & 10 & 9 & 11 & 13 \\
\hline Specific gravity & 1.017 & 1.021 & 1.016 & 1.019 & 1.021 & 1.014 & 1.018 \\
\hline \multicolumn{8}{|l|}{ Retention rate, } \\
\hline $\mathrm{kg} \mathrm{kg}^{-1}$ absorbent & 0 & 1.55 & 1.49 & -0.74 & 1.44 & 0 & 1.58 \\
\hline COD, $\mathrm{mg} \mathrm{l}^{-1} \times 10^{3}$ & 33.7 & 43.4 & 35.8 & 42.8 & 45.2 & 40.8 & 53.2 \\
\hline
\end{tabular}

$\mathrm{Cl}=$ control silage with formic acid, $\mathrm{SBS}=$ unmolassed sugar beet shreds, $\mathrm{RB}=$ rolled barley, $\mathrm{CP}=\mathrm{a}$ commercial product based on molassed sugar beet shreds $(75 \%)$ and wheat bran $(20 \%), \mathrm{C} 2=$ control silage without any additives, MSBS $=$ molassed sugar beet shreds, $\mathrm{FA}=80 \%$ formic acid solution, grFA $=$ granulated formic acid solution, $\mathrm{DM}=\mathrm{dry}$ matter, $\mathrm{FM}=$ fresh matter, $\mathrm{COD}=$ chemical oxygen demand

nol and lactic acid production were highest, had the lowest sugar content. Differences between silages in contents of crude fibre and $\mathrm{N}$-free extract were small. The ash content of SBS ensiled with grFA was conspicuously high.

All silages were well preserved (Table 3 4). Only the control silage ensiled without any additive (C2) contained $\mathrm{NH}_{3}$ over $80 \mathrm{~g} \mathrm{~kg}^{-1}$ total nitrogen. Butyric acid was encountered in small amounts in silage SBS ensiled with grFA. None of the absorbents incorporated in formic acidtreated silage $(\mathrm{C} 1)$ had a marked effect on silage quality with the exception of SBS in combination with formic acid, which improved silage fermentation owing to the lower $\mathrm{NH}_{3}-\mathrm{N}$ content. The results for RB are consistent with those of Johnson (1992) and Done (1988), who found that RB used as an absorbent did not improve fermentation quality in silage prepared without any additives. In the untreated control silage (C2), fermentation quality as reflected by lower ammonia $\mathrm{N} /$ total $\mathrm{N}$ and acetic acid content and $\mathrm{pH}$ was clearly increased by MSBS inclusion. Be- cause of the more extensive lactic acid fermentation in silages not treated with formic acid, $\mathrm{pH}$ values were generally higher in silages treated with formic acid than in untreated silages, as was found also by Offer and Al-Rwidah (1989).

\section{Digestibility, intake and growth rate}

In general, diet organic matter digestibility was not affected $(\mathrm{p}>0.05)$ by silage absorbent treatment (Table 5). Digestibility of SBS silage was, however, increased when grFA was used as an additive ( $\mathrm{p}=0.0003$ ) owing to the nutrient absorption capacity of the grFA product. This silage also showed the highest digestibility $(80.6 \%)$. The formic acid-treated control silage (C1) had the lowest digestibility (77.1\%). In the study of Mannerkorpi and Toivonen (1993), inclusion of SBS and MSBS increased the in vitro organic matter digestibility of silages. Offer and AlRwidah (1989) likewise found that silage digestibility in vitro was improved by the addition of 


\section{Sormunen-Cristian, $R$. \& Mannerkorpi, P. Feeding value of grass ensiled with absorbents}

Table 3. Quality of silages at silo opening (C2 sample is taken 28 days earlier) with standard deviation. In each figure pair the upper figure is the mean and the lower figure the standard deviation.

\begin{tabular}{|c|c|c|c|c|c|c|c|}
\hline \multirow{4}{*}{$\begin{array}{l}\text { Absorbent } \\
\text { Silage additive } \\
\text { Number of samples }\end{array}$} & \multicolumn{7}{|c|}{ Silages } \\
\hline & $\mathrm{Cl}$ & SBS & SBS & $\mathrm{RB}$ & $\mathrm{CP}$ & $\mathrm{C} 2$ & MSBS \\
\hline & FA & FA & grFA & FA & FA & - & - \\
\hline & 4 & 4 & 4 & 4 & 4 & 1 & 4 \\
\hline \multirow[t]{2}{*}{ DM, $\mathrm{g} \mathrm{kg}^{-1}$} & 197 & 215 & 222 & 224 & 218 & 195 & 212 \\
\hline & 1.2 & 3.4 & 5.4 & 6.1 & 4.4 & & 2.5 \\
\hline \multicolumn{8}{|l|}{ In silage DM, $\mathrm{g} \mathrm{kg}^{-1}$} \\
\hline \multirow[t]{2}{*}{ WSCs } & 92 & 109 & 92 & 89 & 122 & 29 & 24 \\
\hline & 6.9 & 2.7 & 6.8 & 20.3 & 5.1 & & 1.4 \\
\hline \multirow[t]{2}{*}{ Lactic acid } & 8.6 & 7.8 & 9.2 & 19.2 & 10.3 & 93.2 & 87.2 \\
\hline & 1.3 & 1.4 & 1.4 & 2.9 & 2.2 & & 2.5 \\
\hline \multirow[t]{2}{*}{ Formic acid } & 12.3 & 10.7 & 18.4 & 10.9 & 11.9 & 0.5 & 0.5 \\
\hline & 4.0 & 1.9 & 3.1 & 2.8 & 0.8 & & 0.4 \\
\hline \multirow[t]{2}{*}{ Asetic acid } & 18.5 & 18.4 & 12.7 & 13.8 & 14.7 & 26.1 & 19.9 \\
\hline & 5.1 & 2.8 & 0.3 & 1.3 & 0.7 & & 1.5 \\
\hline \multirow[t]{2}{*}{ Butyric acid } & 0.3 & 0 & 0 & 0 & 0 & 0 & 0 \\
\hline & 0.3 & & & & & & \\
\hline \multirow[t]{2}{*}{ Ethanol } & 10.0 & 6.5 & 9.4 & 19.9 & 5.2 & 11.3 & 25.0 \\
\hline & 1.2 & 1.0 & 1.2 & 0.4 & 0.5 & & 1.3 \\
\hline \multirow[t]{2}{*}{ Total-N } & 23.6 & 22.4 & 21.5 & 22.9 & 23.1 & 22.4 & 22.8 \\
\hline & 0.5 & 0.6 & 0.3 & 0.4 & 0.9 & & 0.5 \\
\hline \multirow[t]{2}{*}{$\mathrm{NH}_{3}-\mathrm{N} / \mathrm{N}$} & 33.4 & 25.0 & 28.8 & 47.3 & 27.3 & 54.9 & 54.7 \\
\hline & 7.1 & 2.0 & 1.4 & 3.7 & 1.8 & & 2.0 \\
\hline \multirow[t]{2}{*}{ Soluble-N/N } & 389.1 & 359.7 & 425.9 & 515.8 & 408.7 & 558.4 & 538.8 \\
\hline & 77.9 & 55.7 & 10.9 & 18.5 & 13.5 & & 15.4 \\
\hline \multirow[t]{2}{*}{$\mathrm{pH}$} & 4.19 & 4.07 & 3.92 & 4.18 & 4.32 & 3.94 & 3.98 \\
\hline & 0.10 & 0.04 & 0.03 & 0.05 & 0.05 & & 0.03 \\
\hline
\end{tabular}

$\mathrm{Cl}=$ control silage with formic acid, $\mathrm{SBS}=$ unmolassed sugar beet shreds, $\mathrm{RB}=$ rolled barley, $\mathrm{CP}=\mathrm{a}$ commercial product based on molassed sugar beet shreds $(75 \%)$ and wheat bran $(20 \%), \mathrm{C} 2=$ control silage without any additives, MSBS $=$ molassed sugar beet shreds, $\mathrm{FA}=80 \%$ formic acid solution, grFA $=$ granulated formic acid solution, $\mathrm{DM}=$ dry matter, WSCs = water-soluble carbohydrates

MSBS and RB. Lambs offered absorbent-treated silage had significantly higher OM intakes of ensiled material than those offered untreated silage (SBS+RB+CP vs. $\mathrm{C} 1, \mathrm{p}=0.004$, MSBS vs. $\mathrm{C} 2, \mathrm{p}=0.0001$ ) (Table 5). Intake of diet organic matter was about $29 \%$ higher for lambs receiving silages treated with sugar beet shreds than untreated silages. This finding suggests that the increased intake for treated silages was not a result of better silage digestibility but of either palatability or the effect of absorbent treatment on rumen fermentation kinetics. In general, in- take was higher for the absorbents with the most efficient effluent retention rates.

The observed positive effects of absorbents on intake are consistent with the findings of Jones et al. (1990), Johnson (1992) and Davies and Perrott (1991), but not with the observation of Kennedy (1988), who reported that intake by cattle receiving $2 \mathrm{~kg}$ of supplementary feed head ${ }^{-1}$ day $^{-1}$ was unaffected by absorbent treatment. In the study of Done and Appleton (1988), MSBS, but not RB, treatment improved the daily DM intake. In our study, intake of silage treat- 
Vol. 6 (1997): 173-182.

Table 4. Chemical composition and quality of silages in ad libitum feeding period.

\begin{tabular}{|c|c|c|c|c|c|c|c|}
\hline \multirow{4}{*}{$\begin{array}{l}\text { Absorbent } \\
\text { Silage additive } \\
\text { Number of samples }\end{array}$} & \multicolumn{7}{|c|}{ Silages } \\
\hline & $\mathrm{Cl}$ & SBS & SBS & RB & $\mathrm{CP}$ & $\mathrm{C} 2$ & MSBS \\
\hline & FA & FA & grFA & FA & FA & - & - \\
\hline & 1 & 1 & 1 & 1 & 1 & 1 & 1 \\
\hline $\begin{array}{l}\mathrm{DM}, \mathrm{g} \mathrm{kg}^{-1} \\
\text { In silage DM, } \mathrm{g} \mathrm{kg}^{-1}\end{array}$ & 202 & 215 & 226 & 223 & 218 & 217 & 212 \\
\hline Ash & 81 & 83 & 130 & 80 & 87 & 99 & 90 \\
\hline Crude protein & 152 & 149 & 142 & 158 & 145 & 147 & 151 \\
\hline Ether extract & 51 & 44 & 42 & 49 & 44 & 54 & 48 \\
\hline $\mathrm{N}$-free extract & 403 & 429 & 391 & 433 & 496 & 428 & 415 \\
\hline Crude fibre & 313 & 295 & 295 & 280 & 278 & 278 & 296 \\
\hline NDF & 573 & 560 & 546 & 542 & 519 & 539 & 533 \\
\hline $\mathrm{ADF}$ & 326 & 309 & 300 & 287 & 292 & 302 & 300 \\
\hline WSCs & 25 & 88 & 56 & 8 & 98 & 13 & 12 \\
\hline Lactic acid & 25.3 & 13.0 & 11.1 & 44.0 & 23.4 & 100.7 & 85.1 \\
\hline Formic acid & 10.4 & 9.8 & 11.5 & 2.7 & 7.3 & 0 & 0 \\
\hline Acetic acid & 23.3 & 18.2 & 21.2 & 17.9 & 16.5 & 27.7 & 18.9 \\
\hline Butyric acid & 0 & 0 & 0.4 & 0 & 0 & 0 & 0 \\
\hline Ethanol & 25.8 & 21.9 & 25.2 & 44.0 & 13.3 & 10.6 & 26.5 \\
\hline Total-N & 22.5 & 22.6 & 21.6 & 24.0 & 22.5 & 24.0 & 22.7 \\
\hline $\mathrm{NH}_{3}-\mathrm{N} / \mathrm{N}$ & 44.2 & 26.7 & 30.8 & 69.3 & 55.1 & 84.6 & 54.1 \\
\hline Soluble-N/N & 445.9 & 397.1 & 439.4 & 496.3 & 428.6 & 573.1 & 540.1 \\
\hline $\mathrm{pH}$ & 4.14 & 4.12 & 4.02 & 4.18 & 4.18 & 4.04 & 4.01 \\
\hline
\end{tabular}

$\mathrm{Cl}=$ control silage with formic acid, $\mathrm{SBS}=$ unmolassed sugar beet shreds, $\mathrm{RB}=$ rolled barley, $\mathrm{CP}=\mathrm{a}$ commercial product based on molassed sugar beet shreds $(75 \%)$ and wheat bran $(20 \%), \mathrm{C} 2=$ control silage without any additives, MSBS $=$ molassed sugar beet shreds, $\mathrm{FA}=80 \%$ formic acid solution, grFA $=$ granulated formic acid solution, $\mathrm{DM}=$ dry matter, $\mathrm{NDF}=$ neutral detergent fibre, $\mathrm{ADF}=$ acid detergent fibre, WSCs = water-soluble carbohydrates

ed with RB was also noticeably lower than that of silages treated with sugar beet shreds, most likely due to silage fermentation quality. Furthermore, the RB silage had an unpleasant mucous consistency and a particularly sweet smell. Voluntary feed intake can be reduced by a high lactic acid content of silage (McLeod et al. 1970). The high lactic acid content in MSBS silage without formic acid treatment may partly explain why intake of this silage was lower than that of other sugar beet shred-treated silages. The most palatable SBS-grFA silage included butyric acid. Experience has shown that butyric acid does not necessarily affect silage intake (Sormunen-Cristian 1984).

The use of sugar beet shreds as absorbents improved the diet ME value ( $\mathrm{p}=0.003)$ and live weight gains of lambs $(\mathrm{p}=0.02)$. Daily growth of lambs was highest with SBS silage $(124 \mathrm{~g})$, next highest with SBS ensiled with grFA (108 g) and lowest with RB (36 g). Incorporation of sugar beet shreds has yielded a tendency towards higher lamb live weight gains (Done 1988), but the improvement in silage ME value has been slight (Offer and Rwidah 1988). One of the lambs in the group fed RB silage lost weight and two of them did not grow at all.

All the above findings refer to an absorbenttreated grass silage compared with pure grass silage. If the objective is to establish whether there is a difference between absorbent/concentrate added at ensiling and that fed separately, a different 
Sormunen-Cristian, R. \& Mannerkorpi, P. Feeding value of grass ensiled with absorbents

Table 5. Digestibility and intake of silage (grass silage with absorbent) and of diet (silage plus soya-bean meal) and growth rate of lambs in ad libitum period.

\begin{tabular}{|c|c|c|c|c|c|c|c|c|c|c|c|c|}
\hline \multirow{3}{*}{$\begin{array}{l}\text { Absorbent } \\
\text { Silage additive }\end{array}$} & \multicolumn{7}{|c|}{ Silages } & \multirow{3}{*}{ SEM } & \multicolumn{4}{|c|}{ Contrasts } \\
\hline & $\mathrm{Cl}$ & SBS & SBS & RB & $\mathrm{CP}$ & $\mathrm{C} 2$ & MSBS & & $\mathrm{SBS}+\mathrm{RB}+\mathrm{CP}$ & MSBS & SBS(FA) & SBS \\
\hline & FA & FA & grFA & FA & FA & - & - & & vs. $\mathrm{Cl}$ & vs. C2 & vs.SBS(grFA) & )vs.CP \\
\hline \multicolumn{13}{|l|}{ Silage: } \\
\hline Digestibility of OM (\%) & 74.7 & 76.1 & 79.4 & 76.2 & 75.6 & 76.4 & 77.0 & 0.56 & & & & \\
\hline Voluntary intake of OM & & & & & & & & & & & & \\
\hline$\left(\mathrm{g}_{\text {day }}{ }^{-1}\right)$ & 658 & 798 & 816 & 710 & 831 & 518 & 774 & 31.8 & & & & \\
\hline$\left(\mathrm{g} \mathrm{kg}^{-1} \mathrm{~W}^{0.75}\right)$ & 43 & 51 & 51 & 46 & 53 & 33 & 49 & 2.0 & & & & \\
\hline \multicolumn{13}{|l|}{ Diet: } \\
\hline Digestibility of $\mathrm{OM}(\%)$ & 77.1 & 77.8 & 80.6 & 78.0 & 77.4 & 79.0 & 78.7 & 0.49 & NS & NS & 0.0003 & NS \\
\hline Metabolisable energy") & & & & & & & & & & & & \\
\hline$\left(\mathrm{MJ} \mathrm{kg}^{-1} \mathrm{DM}\right)$ & 10.9 & 11.2 & 11.2 & 11.3 & 11.1 & 11.1 & 11.3 & 0.08 & 0.003 & 0.01 & NS & NS \\
\hline $\begin{array}{l}\text { Voluntary intake of OM } \\
\left(\mathrm{g} \mathrm{day}^{-1}\right)\end{array}$ & 823 & 963 & 881 & 964 & 996 & 683 & 939 & 32.9 & 0.004 & 0.0001 & NS & NS \\
\hline$\left(\mathrm{g} \mathrm{kg}^{-1} \mathrm{~W}^{0.75}\right)$ & 53 & 62 & 62 & 56 & 64 & 44 & 60 & 2.1 & 0.005 & 0.0001 & NS & NS \\
\hline Voluntary intake of DOM & & & & & & & & & & & & \\
\hline$\left(\mathrm{g}_{\text {day }}{ }^{-1}\right)$ & 634 & 749 & 791 & 676 & 771 & 538 & 737 & 26.0 & 0.002 & 0.0001 & NS & NS \\
\hline$\left(\mathrm{g} \mathrm{kg}^{-1} \mathrm{~W}^{0.75}\right)$ & 41 & 48 & 50 & 44 & 49 & 35 & 47 & 1.6 & 0.003 & 0.0001 & NS & NS \\
\hline Growth rate, $g$ lamb ${ }^{-1}$ day -1 & -141 & 124 & 108 & 36 & 89 & 48 & 86 & 15.6 & 0.02 & NS & NS & NS \\
\hline
\end{tabular}

$\mathrm{C} 1=$ control silage with formic acid, $\mathrm{SBS}=$ unmolassed sugar beet shreds, $\mathrm{RB}=$ rolled barley, $\mathrm{CP}=\mathrm{a}$ commercial product based on molassed sugar beet shreds $(75 \%)$ and wheat bran $(20 \%), \mathrm{C} 2=$ control silage without any additives, MSBS = molassed sugar beet shreds, $\mathrm{FA}=80 \%$ formic acid solution, grFA = granulated formic acid solution, $\mathrm{SEM}=\mathrm{standard}$ error of means, $\mathrm{OM}=$ organic matter, $\mathrm{DM}=$ dry matter, $\mathrm{DOM}=$ digestible organic matter, $\mathrm{W}^{0.75}=$ metabolic live weight, $\mathrm{NS}=$ non significant

type of experiment must be carried out. According to the results of Johnson (1992), a greater increase in animal live weight gain could be expected if the same amounts of RB were fed separately with untreated silage rather than as an absorbent. In contrast, Done and Appleton (1998) found no evidence of better performance in lambs fed a "complete" diet than in those offered silage and supplement as separate components.

\section{Conclusions}

In general, there was no difference between SBS, MSB and CP silages in the animal parameters measured. The use of grFA product did not reduce effluent production but it clearly decreased effluent COD and thereby silage digestibility without affecting growth of lambs. Incorporation of MSBS without formic acid treatment improved silage quality and increased intake, but did not affect lamb growth. Further, it reduced effluent production but increased its COD. Rolled barley did not retain silage effluent, nor was the silage palatable for the lambs. In view of the effects on effluent COD, digestibility and silage intake, it is recommended that SBS be used as absorbent and grFA as silage additive.

Acknowledgements. The authors wish to thank the technical staff of Animal Nutrition Section of Agricultural Research Centre for their assistance in conducting the trial. 
Vol. 6 (1997): 173-182.

\section{References}

Barker, S.B. \& Summerson, W.H. 1941. The colorimetric determination of lactic acid in biological material. Journal of Biological Chemistry 138: 53-553.

Davies, O.D. \& Perrott, J.G. 1991. The effects of ensiling molassed sugar beet feed with grass on dairy cow performance. Animal Production 52: 588-589. (Abstract).

Dexter, S. 1961. Water retaining capacity of various silage additives and silage crops under pressure. Agronomy Journal 53: 379-381.

Done, D.L. 1988. The effect of absorbent additives on silage quality and on effluent production. In: Stark, B.A. \& Wilkinson, J.M. (eds.) Silage effluent. Problems and solutions. p. 49.

- \& Appleton, M. 1985. The effect of absorbent additives on silage quality and effluent production. In: Mayne, C.S. (ed.). Silage for milk production. Occasional Symposium no 23, British Grassland Society. p. 190192.

Gordon, C.H. 1967. Storage losses in silage as affected by moisture content and structure. Journal of Dairy Science 50: 397-403.

Huida, L. 1973. Haihtuvien rasvahappojen kvantitatiivinen măărittăminen pōtsinesteestă ja săilörehusta kaasunestekromatografisesti. Journal of the Scientific Agricultural Society of Finland 45: 483-488.

- 1982. Gas chromatographic determination of water and ethanol in silage by internal standard methods. Journal of the Scientific Agricultural Society of Finland 54: 137-143.

- , Văătăinen, H. \& Lampila, M. 1986. Comparison of dry matter contents in grass silages as determined by oven drying and gas chromatographic water analysis. Annales Agriculturae Fenniae 25: 215-230.

Johnson, P.N. 1992. The effect of various rates of rolled barley as absorbents on effluent production silage fermentation and animal performance. Proceedings of the 14th General Meeting of the European Grassland Federation, June 8-11, 1992. Lahti, Finland. $752 \mathrm{p}$.

Jones, D.I.H., Jones, R. \& Moseley, G. 1990. Effect of incorporating rolled barley in autumn-cut ryegrass silage on effluent production, silage fermentation and cattle performance. Journal of Agricultural Science, Cambridge 115: 399-408.

Kennedy, S.J. 1988. An absorbing experiment. In: Stark, B.A. \& Wilkinson, J.M. (eds.) Silage effluent. p. 5253.
- \& Moore, C.A. 1988. The use of a silage effluent absorbent. Occasional Research Meeting, British Grassland Society, Aberystwyth, September 1988. p. 107-108.

MAFF 1975. Energy allowances and feeding systems for ruminants. Technical Bulletin 33. London. 79 p.

Mannerkorpi, P. \& Toivonen, V. 1993. Effect of ensiling grass with absorbents on effluent production and composition and silage quality. Proceedings of the 10th International Conference on Silage Research, Dublin, Ireland. p. 102-103.

McCullough, H. 1967. The determination of ammonia in whole blood by a direct colorimetric method. Clinica Chimica Acta 17: 297-304.

McLeod, D.S., Wilkins, R.J. \& Raymond, W.F. 1970. The voluntary intake by sheep and cattle of silage differing in free-acid content. Journal of Agricultural Science, Cambridge 75: 311-319.

Offer, N.W \& Al-Rwidah, M.N. 1989. The use of absorbent materials to control effluent loss from grass silage: experiments with drum silos. Research and Development in Agriculture 6: 71-76.

Purves, D. \& McDonald, P. 1963. Potential value of silage effluent as a fertilizer. Journal of British Grassland Society 18: 220-222.

Robertson, J.B. \& Van Soest, P.J. 1981. The detergent system of analysis and its application to human foods. In: James, W.D. \& Theander, O. (eds.). The analysis of dietary fiber in foods. New York, Marcell Decker. p. 123-158.

Salo, M.-L., Tuori, M. \& Kiiskinen, T. 1990. Rehutaulukot ja ruokintanormit. Helsinki. 70 p.

SAS 1992. SAS system for linear models. SAS Institute Inc., Cary, NC, USA. 329 p.

Somogyi, M. 1945. A new reagent for the determination of sugars. Determination of blood sugar. Journal of Biological Chemistry 160: 61-73.

Sormunen-Cristian, R. 1984. Hay and silage as forage for sheep. Fårens utfodring och skötsel under vinterperioden. NJF's seminarium nr. 59, 25-27 April 1984 på Tune, Danmark.

Spörndly, R. 1986. Ensiling of blended grass and grain and its utilisation by dairy cows. Report Swedish University of Agricultural Sciences, Uppsala No. 155.

Van Keulen, J. \& Young, B. A. 1977. Evaluation of acid insoluble ash as a natural marker in ruminant digestibility studies. Journal of Animal Science 44: 282287. 
Sormunen-Cristian, R. \& Mannerkorpi, P. Feeding value of grass ensiled with absorbents

\title{
SELOSTUS
}

\section{Eri absorbenteilla valmistettu säilörehu karitsoiden ruokinnassa}

\author{
Riitta Sormunen-Cristian ja Päivi Mannerkorpi \\ Maatalouden tutkimuskeskus
}

Säilörehusiilojen täytön yhteydessä ruohon joukkoon lisättiin kerroksittain $(50 \mathrm{~kg} / 1000 \mathrm{~kg}$ rehua $)$ absorbenteiksi puristeleikettä (melassoimaton leike), säilöleikettä (75\% melassileikettä ja $20 \%$ vehnänlesettä), litistettyä ohraa ja melassileikettä. Säilöntäaineena käytettiin AIV II-liuosta sekä granuloitua muurahaishappovalmistetta tai säilöntäainetta ei käytetty lainkaan. Puristenesteen ympäristöä kuormittavaa vaikutusta selvitettiin mittaamalla, kuinka paljon absorbentit pidättivät puristenestettä sekä mikä oli puristenesteen kemiallinen hapenkulutus (COD). Säilörehujen maittavuutta, rehuarvoa ja sulavuutta tutkittiin kasvavilla karitsoilla. Vapaan säilörehuruokinnan lisäksi karitsat saivat soijaa 200 g eläintä kohti päivässä. Koko rehuannoksen sulavuus määritettiin käyttämällä happoon liukenematonta tuhkaa rehun sisäisenä merkkiaineena.

Ympäristöystävällisin absorbentti-säilöntäainepari saatiin rehulla, joka valmistettiin granuloidulla muurahaishapolla ja absorbenttina käytettiin puristeleikettä. Ohra ei sitonut puristenestettä lainkaan. Ko- konaishapen kulutusta kasvattava tekijä oli selvästi absorbenttien ravinnepitoisuus ja ravinteiden liukeneminen puristenesteen mukana. Absorbenttien käyttäminen ei vaikuttanut rehuannoksen sulavuuteen. Parhain orgaanisen aineen sulavuus $(80,8 \%)$ oli rehulla, joka oli valmistettu granuloidulla muurahaishapolla ja jossa absorbenttina oli puristeleike ja huonoin $(77,3 \%)$ AIV II:lla valmistetulla kontrollisäilörehulla.

Karitsat söivät eniten leikkeillä valmistettuja säilörehuja sekä kasvoivat niillä myös parhaiten. Kokeellisen granuloidun muurahaishappovalmisteen käyttäminen AIV II-liuoksen sijasta ei vähentänyt puristenesteen erittymistä, mutta se vähensi huomattavasti puristenesteen kemiallista hapenkulutusta sitoen siis ravinteita. Melassileike paransi säilörehun laatua ja vähensi puristenesteen eritystä verrattuna painorehuun, mutta se nosti puristenesteen kemiallista hapenkulutusta. Melassoimattoman puristeleikkeen käyttö absorbenttina osoittautui tuloksiltaan parhaimmaksi. 